\title{
Effectiveness of Subtle Value Movements in the Development of Theoretical Models of Organizational Performance
}

\author{
Endro Sugiartono ${ }^{1}$, Retno Sari Mahanani ${ }^{2 *}$, and Bagus Putu Yudhia Kurniawan ${ }^{3}$ \\ 1, 2, 3 Agribusiness Management, Politeknik Negeri Jember, Indonesia \\ *Corresponding author. Email: retno7089@gmail.com
}

\begin{abstract}
The research gap examined over entrepreneurial culture conflicts with improving organizational performance by incorporating fair values as factors that can improve organizational performance. Four hypotheses were developed and tested in a sample of 110 coffee processing factories in Jember, Indonesia. The study's findings suggest an essential role in sub-moving values' effectiveness in mediating an entrepreneurial culture in improving organizational performance. The research also builds a conceptual model for business operations from a business culture by synthesizing the effectiveness of well-moving values.
\end{abstract}

Keywords: effectiveness of subtle value movements, theoretical model, organizational performance

\section{INTRODUCTION}

Coffee is a popular drink created by steeping roasted and ground coffee beans in water. Coffee is the second most popular beverage in the world. Coffee has developed from a simple drink to a way of life, so it's no wonder that it's one of the world's most regularly exported and traded commodities. After Brazil, Vietnam, and Colombia, Indonesia is the world's fourth-largest coffee grower and exporter. Coffee is a cornerstone commodity of plantations, contributing considerably to the Indonesian economy, and is a government priority for future agricultural expansion in Indonesia.

As millennial lifestyles and the digital sector evolve, entrepreneurs cultivate and market coffee beautifully packaged and innovative. Coffee shops in Indonesia until August 2019 reached more than 2950 stores, a sharp increase compared to 2016 [1]. Indonesia still has national challenges dealing with low-quality human resources despite developing coffee processing and marketing products. Human resources' capability has remained low until now, both in intellectual understanding and technical abilities [2]. Regional economic development addresses the cultural function of entrepreneurship with non-economic components. [3].
According to the research findings, entrepreneurship culture substantially impacts performance [4]. However, other research demonstrates the contrary, namely that organizational culture (entrepreneurial cultural factor) does not affect organizational performance [5]. The performance paradox of entrepreneurial culture refers to the disparity in the study's findings. Due to the varied effects of a performance entrepreneurship culture, determine the best techniques to foster an entrepreneurial culture capable of boosting business performance.

This study's objective was to close a research gap. by using a theory of planned behaviour. The theory of planned behaviour highlights a person's beliefs and actions. According to this idea, perceived attitudes, norms, and behavioural controls all work together to form an individual's intentions and conduct. Perceived behavioural control shapes entrepreneurial choices, personal beliefs, and social conventions that influence the intended behaviour. [6]. According to some viewpoints, self-efficacy theory is a vital component of theoretical frameworks for cognitive, social, and social learning. It refers to a person's perception that they can do a task and motivate themselves to accomplish the desired results [7]. According to another viewpoint, self-efficacy is an individual's perception that they have the power to exert control over the work of environmental circumstances [8]. The element that influences high levels of self- 
efficacy is previous personal experience, shared experiences, social persuasion, and physiological and emotional states [9].

Value resides exclusively in the human mind and not in the real world. A value is a behavior standard, a measurement that specifies criteria that color how people behave. Establishing an attitude or mentality or a person's proclivity for an object is how a person commits to a given value. Their level of cognition and skill determines a person's attitude toward an item in motion. The process of providing guidance, absorption, or providing examples and directives can all result in the formation of a mood.

For an entrepreneurial culture to impact organizational performance, it must deliver innovative and original strategies and rapid growth [10]. Suggestions, independence, bravery, responsibility, creativity, patience, honesty, and leading by example with a fluid flowing approach through counsel, model, and order, as well as support from others, may all have an impact on the establishment of a value system, attitude, and mindset in business [11].

Empirical studies propose an advanced concept and, as a comparison in previous research that addresses value effectiveness, which moves smoothly to moderate the impact of entrepreneurial culture on improving organizational performance [12]. With a research subject from the Jember Coffee Processing Industry, Indonesia, the study fills research gaps in empirical investigations by developing conceptual models of entrepreneurial culture, the effectiveness of progressive values, and organizational performance.

\section{CONCEPTUAL BACKGROUND}

\subsection{Finely Moving Values' Effectiveness Planned Behavior Theory's Framework}

Values are behavioural norms, a metric that establishes a criterion and colours a person's actions. Value resides exclusively in the human mind and not in the real worldAccording to research, cultivating values starts with teaching the correct values knowledge. Followed by setting a good example, becoming accustomed to doing the right thing, allowing them to examine issue circumstances, acquire insight, weigh certain attitudes toward the values they hold, and encouraging them to frame their actions [13].

Entrepreneurial ideas, such as their role in shaping entrepreneurial behavior and independence, must be cultivated to produce an excellent behavioural order [14]. Planned behaviour theory, stated quickly in psychology, is a hypothesis that connects a person's ideas to their actions [15]. According to the theory, a combination of attitudes shapes an individual's intentions and behaviour, subject norms, and perceived behavioural restrictions. Icek Ajzen suggested incorporating perceived behavioural control into reasoned action theory to improve its predictive value. It has investigated the interaction of ideas, attitudes, behavioral intentions, and behavior in numerous disciplines. Advertising and advertising campaigns, public relations, health care, sports management, and sustainability are all examples of services provided [15].

Behavioural control, personal attitudes, and societal conventions all have a role in the success of planned action in growing entrepreneurial value intentions. The effectiveness of values and related behaviours must combine with effective behavioural transparency strategies. This brilliant idea can develop values, attitudes, mental and moral systems, hence reducing poverty in disadvantaged communities [16]. The investigation of the effectiveness of behavioral ideals and examples has its origins in various fields, including psychological science and planned behavioural theory. [17], Social psychology [18], sociology [19], economics and business [20]; [10]; [21]. As stated in the social side of psychology, cultivating the mentality of entrepreneurship through the development of virtues such as independence, bravery, responsibility, creativity, patience, honesty, as well as providing an excellent example by a subtle approach or movement, can help to cultivate the mentality of entrepreneurship [18].

As soon as possible, beginning with the family must instill its values and culture because entrepreneurship is still not the most popular job in society. It must effectively develop new and distinctive tactics [22]; [23]. Using a fundamental approach to example allows for the effective incorporation of entrepreneurial culture values [18]; [21]. Synthesis of principles of the efficacy of innovative techniques, the development of example behavioral value systems, and methodology of smooth movements is the efficacy of a well-moving weight.

\subsection{The Effectiveness of Finely Moving Values and an Entrepreneurial Culture}

Kirzerian entrepreneurship theory, explaining in a complex manner about economic, sociological, psychological, and entrepreneurial behaviour, has evolved the study of entrepreneurial culture [24]. It then complements the conceptual culture of the organization, which defines it as shared ideas and values that contribute to the formation of behavioral patterns [25]. Entrepreneurship is a long-term process, and the type of business undertaken can be influenced by societal and cultural values [26]. Entrepreneurial goals influence competing desires, individual perceptions of personal control, and attitudes [27]. Other research has found that an entrepreneurial culture is characterized by openness to change, self-efficacy, and inventiveness [28].

Entrepreneurial culture is a strategic instrument for emphasizing socio-cultural principles of 
entrepreneurship and self-control for entrepreneurial intentions. A smooth-moving transparency approach can complement the efficacy of value-based entrepreneurial strategies. As a result, it proposes the following hypothesis:

$\mathbf{H}_{1}$ :Entrepreneurial culture in a significant and beneficial way influences the effectiveness of subtly changing values.

\subsection{Finely Moving Values' Effectiveness and Organizational Performance}

This study discusses the ineffectiveness of entrepreneurial culture, which can lead to new and innovative tactics and a rapid increase in supporting performance. Individuals' natures or traits, such as leadership values, are mirrored in how they manage and enhance their own company's success while also providing jobs for others [29]. Entrepreneurial value has a substantial and favourable impact on business independence. A business action's worth contains a mental component that broadens one's perspectives. Therefore, it is a type of conduct in business management that leads to business independence [30]. Entrepreneurial values can impact behaviour in operating a firm since they are the foundation for understanding their attitude and drive. Therefore, the deal is significant in managing business independence [31]. Another point of view shows that mothers' actions in fostering and building an entrepreneurial culture through examples with family children are very effective. It can improve a child's capacity to identify business prospects, the availability of proper facilities, and a child's excellent intellect and inventiveness, leading to increased entrepreneurial behavior [18]. As a result, it proposes the following hypothesis:

$\mathbf{H}_{2}$ :The impact of finely shifting values on organizational performance is significant and favourable.

This research gap and contradictory research on the influence of entrepreneurial culture on organizational performance led the researchers to propose acceptable value effectiveness characteristics used as mediation to improve organizational effectiveness. A variable that intervenes in increasing organizational effectiveness is finely shifting value points. The following factors influenced the study's design: An entrepreneurial culture is vital and crucial in explaining a country's economic success [32]. The regional science and economic geography literature correlate regional economic development with non-economic variables, noting the importance of entrepreneurial culture [33]. Suggestion, independence, courage, creativity, responsibility, honesty, and patience are all aspects of cultivating an entrepreneurial mindset. According to a study by North Sulawesi Province's Ministry of Industry and Trade on the impact of organizational culture on the appearance of the organization, the culture of entrepreneurship does not affect organizational performance. The inability to deliver new and distinct techniques, as well as fast growth, causes these conditions to occur [10]. As cultural mediators of performance, behavior and value mobility are critical. Behaviour has assessed ineffective cultures in managing businesses and helped shift the culture to business success [34].

This concept leads to a view of fine-moving value's effectiveness as a strategic alternative to improve organizational performance. Improved organizational performance through self-efficacy, wild thinking tactics, behavioral value systems, and examples, such as a subtle approach, recognizing entrepreneurial culture as strategic and practical input. As a result, it proposes the following mediating hypothesis

$\mathbf{H}_{3}$ : The ability of finely changing values to mitigate the effect of entrepreneurial mindset on organizational effectiveness is significant and favourable.

Furthermore, the following conceptual framework models show the causal relationship between entrepreneurial culture and the effectiveness of finely changing values and organizational performance.

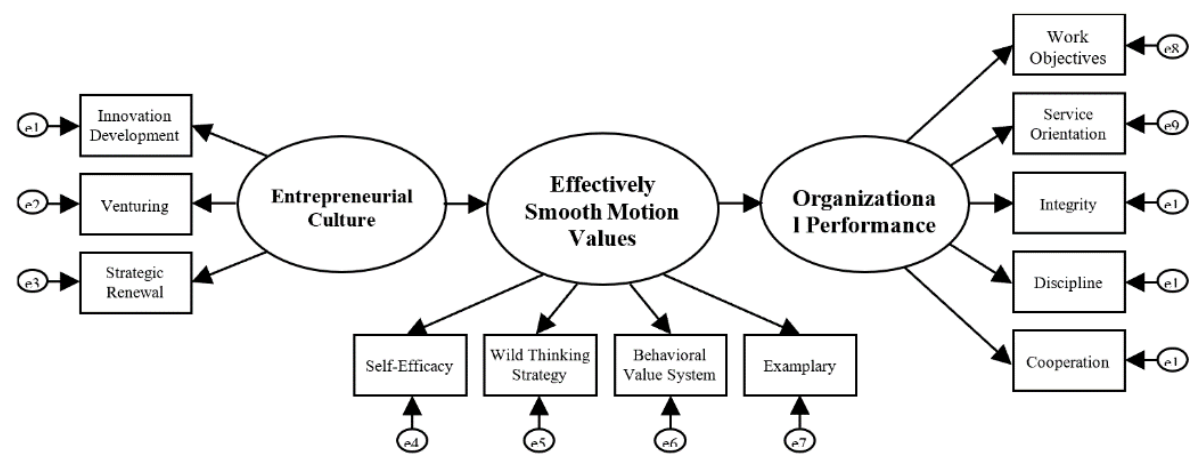

Fig. 1. Conceptual Framework 


\section{RESEARCH METHODS}

This research is a form of survey research. It uses for confirmation or explanation to explain hypothesis testing to determine the effect of factors or causal links. The census technique, or comprehensive enumeration, is used in this study on the entire Jember coffee processing industry of 34 companies. Or in other words, this study does not use samples, so the sampling techniques are also not needed.

The primary data collection conducted a live interview with a coffee processing company in Jember Regency. The questions were methodically structured and led (the correlation coefficient is positive and more significant than 0.30) and reliable (an alpha Cronbach value greater than 0.60). Secondary data of this study takes from data /information owned by related agencies, and the bibliography includes books on literature, scientific journals, and other publications.

The structural equation modeling (SEM) program LISREL 8.8 was used to analyze this study. Use this analysis to meet the requirements and test causal relationships between relatively complex variables [35]; [36].

\section{RESULTS AND DISCUSSION}

\subsection{Results}

Analyze the measurement model's validity by determining if (a) the variable observed in the model qualifies well, i.e., is more important than the critical value (>1.96); and (b) the standardized loading factors of the model's observable variables have qualified successfully, namely $>0.70$. According to Igbaria et al., standardized loading factors $>0.50$ are essential, but if they are $>0.30$, associated variables should not be deleted [37].

To conduct a measurement model reliability study, calculate are construct reliability (CR) and variance extracted (VE) values using standardized loading factors and error variance. Although a good Construct Reliability (CR) number must be more than 0.70 , reliability is still considered high if the CR value is between 0.60 and 0.70 . Nilai VE greater than 0.50 is a reliable indicator [38]. However, in research, this VE is often an option that may be utilized or not included in the study, but it would be preferable if included.

Table 1. Confirmatory factor analysis test validity and reliability measurement model ( $\left.2^{\text {nd }} C F A.\right)$

\begin{tabular}{|l|l|r|l|l|l|l|}
\hline & \multicolumn{3}{|l|}{ Validity } & \multicolumn{2}{l|}{ Reliability } & \multirow{2}{*}{ Information } \\
\cline { 2 - 5 } & SLF & t- & Error & CR & VE & \\
\hline OC & \multicolumn{2}{|l|}{} & 0.85 & 0.67 & \\
X1 & 0.87 & $* *$ & 0.13 & & & Baik \\
X2 & 0.78 & 7.20 & 0.20 & & & \\
X3 & 0.56 & 5.62 & 0.50 & & & \\
\hline
\end{tabular}

\begin{tabular}{|c|c|c|c|c|c|c|}
\hline \multicolumn{4}{|c|}{ ESMV } & \multirow[t]{2}{*}{0.86} & \multirow[t]{2}{*}{0.61} & \multirow{5}{*}{ Baik } \\
\hline Z1 & 0.81 & $* *$ & 0.23 & & & \\
\hline Z2 & 0.64 & 6.54 & 0.41 & & & \\
\hline Z3 & 0.81 & 8.36 & 0.23 & & & \\
\hline Z4 & 0.49 & 4.91 & 0.41 & & & \\
\hline OP & & & & 0.89 & 0.64 & \multirow{6}{*}{ Baik } \\
\hline Y1 & 0.34 & ** & 0.37 & & & \\
\hline Y2 & 0.65 & 3.28 & 0.27 & & & \\
\hline Y3 & 0.88 & 3.44 & 0.12 & & & \\
\hline Y4 & 0.65 & 3.25 & 0.30 & & & \\
\hline Y5 & 0.73 & 3.35 & 0.23 & & & \\
\hline
\end{tabular}

Table 2. The Fit's Quality - $2^{\text {nd }} C F A$

\begin{tabular}{|c|c|c|c|}
\hline & GOF & Estimate & Match \\
\hline 1 & $\begin{array}{l}\text { Chi-Square } \\
\mathrm{P}\end{array}$ & $\begin{array}{l}\chi^{2}=57,79 \\
p=0,135\end{array}$ & Good \\
\hline 2 & $\begin{array}{l}\mathrm{NCP} \\
\text { Interval }\end{array}$ & $\begin{array}{l}10,79 \\
0,0 ; 34,22\end{array}$ & Good \\
\hline 3 & $\begin{array}{l}\text { RMSEA } \\
\text { P (close fit) }\end{array}$ & $\begin{array}{l}0,046 \\
p=0,54\end{array}$ & Good \\
\hline 4 & ECVI & $\begin{array}{l}M^{*}=1,10 \\
S^{*}=1,43 \\
I^{*}=9,22\end{array}$ & Good \\
\hline 5 & AIC & $\begin{array}{l}M^{*}=119,79 \\
S^{*}=156,00 \\
I^{*}=1005,27\end{array}$ & Good \\
\hline 6 & CAIC & $\begin{array}{l}M^{*}=234,50 \\
S^{*}=444,64 \\
I^{*}=1049,68\end{array}$ & Good \\
\hline 7 & NFI & 0,94 & Good \\
\hline 8 & NNFI & 0,98 & Good \\
\hline 9 & $\mathrm{CFI}$ & 0,98 & Good \\
\hline 10 & IFI & 0,98 & Good \\
\hline 11 & RFI & 0,91 & Good \\
\hline 12 & $\mathrm{CN}$ & 130,14 & Good \\
\hline 13 & RMR & 0,042 & Good \\
\hline 14 & GFI & 0,92 & Good \\
\hline 15 & AGFI & 0,87 & Good \\
\hline
\end{tabular}

Table 3. Statistical Test F (Model I)

\begin{tabular}{|c|l|c|c|c|}
\hline & \multicolumn{1}{|c|}{ Hypothesis } & Est. & t- & Conc. \\
\hline H1 & $\begin{array}{l}\text { Entrepreneurial } \\
\text { culture positively } \\
\text { influences the }\end{array}$ & 0.63 & 3.61 & Supported \\
\hline
\end{tabular}




\begin{tabular}{|c|c|c|c|c|}
\hline & $\begin{array}{l}\text { effectiveness of } \\
\text { finely moving value }\end{array}$ & & & \\
\hline $\mathrm{H} 2$ & $\begin{array}{l}\text { The effectiveness of } \\
\text { finely moving values } \\
\text { positively affects } \\
\text { organizational } \\
\text { effectiveness }\end{array}$ & 0.85 & 3.29 & Supported \\
\hline \multirow[t]{5}{*}{ H3 } & $\begin{array}{l}\text { The efficacy of a } \\
\text { subtle-moving value } \\
\text { can moderate the } \\
\text { whole impact of } \\
\text { entrepreneurial } \\
\text { orientation on } \\
\text { organizational } \\
\text { effectiveness }\end{array}$ & \multicolumn{2}{|c|}{$\begin{array}{l}\text { The entire } \\
\text { mediation } \\
\text { effect is } \\
\text { appropriate }\end{array}$} & Supported \\
\hline & P1: $E C \rightarrow O P$ & 0.72 & 2.77 & Supported \\
\hline & P2: EC $\rightarrow$ ESMV & 0.64 & 3.73 & Supported \\
\hline & P3: ESMVC $\rightarrow$ OP & 0.95 & 3.33 & Supported \\
\hline & P4: $\mathrm{EC} \rightarrow \mathrm{OP}$ & 0.44 & 1.01 & $\begin{array}{c}\text { Not } \\
\text { Supported }\end{array}$ \\
\hline
\end{tabular}

\subsection{Discussion}

The measurement model's validity and reliability were tested using Confirmatory Factor Analysis (2nd CFA), which revealed that the entire variable was reliable and valid and met all standards.

The Good of Fit - 2nd CFA test reveals that there are two sizes, GoF, that suggest a terrible fit, and thirteen measurements that give a good fit, implying that the goodness-of-fit model is satisfactory (good fit).

To resolve research gaps in entrepreneurial culture results that inconsistently impact organizational performance, use the efficacy of accepted shifting value as a mediation variable between entrepreneurial culture and organizational performance. As a result, the mediation effect hypothesis must be tested. Adopt the procedure [39] to put mediation to the test, specifically: (1) h current there is a substantial correlation between the independent and dependent variables; (2) h current there is a significant regression coefficient of independent variables against mediation variables; (3) $\mathrm{h}$ current there is a coefficient of regression from the mediator variable to the predictor variables; and (4) When mediation factors are included in the model, the significant regression coefficient from the independent variable to the dependent variable must be significantly lowered or become insignificant. To do so, by running back, Table 8 shows the model with these four stages at the bottom. When the model takes into account the efficacy of finely shifting values, the influence of entrepreneurship development on organizational effectiveness becomes reduced ( 0.50 to 0.22$)$ and inconsequential, indicating the full mediation effect of the effectiveness of finely moving value to close the gap in studies between entrepreneurship culture and organizational effectiveness.

\section{CONCLUSION}

As a strategic input, entrepreneurial culture has shown to be an influential variable in increasing the efficacy of values that flow smoothly and strengthening the study of the construction of value systems, attitudes, and mindsets in entrepreneurship — better organizational performance. It is strengthening planned behaviour theory. Because an entrepreneurial culture is the first step to enhancing values, attitudes, and mentality, it is logical that it is the initial step toward proving the efficacy of specific behaviors. A progressive entrepreneur needs to strategically apply a subtle value-effective approach to improve their organization's performance.

\section{AUTHORS' CONTRIBUTIONS}

ES, RSM, and BPYK contributed conception and conduct of the study, the interpretation of findings, and a text draft.

\section{ACKNOWLEDGMENTS}

The Ministry of Research Technology and Higher Education, the Republic of Indonesia, supports this Research in Jember State Polytechnic.

\section{REFERENCES}

[1] J. Hasanah, "\#GerakBersama: Kolaborasi Ciamik Kedai Kopi dan UKM Lokal Kota Jember di Tengah Pandemi," Konfirmasi Times, Jember, May 2020.

[2] H. T. Koesmono, "Pengaruh Budaya Organisasi Terhadap Motivasi dan Kepuasan Kerja Serta Kinerja Karyawan pada Sub Sektor Industri Pengolahan Kayu Skala Menengah di Jawa Timur," Manajemen \& Kewirausahaan, vol. 7, no. 2, pp. 171-188, 2005.

[3] S. Beugelsdijk, "Entrepreneurial Culture, Regional Innovativeness and Economic Growth," ERSA Conference Papers, vol. 04, p. 210, 2004.

[4] H. Welsa, "Pengaruh Kewirausahaan Terhadap Kemampuan Usaha Serta Kinerja Usaha," Ekuitas, vol. 13, no. 3, pp. 371-387, 2006.

[5] G. Sengke, "The Effect of Organizational Culture Towards Organizational Performance At Dinas Perindustrian Dan Perdagangan Provinsi Sulawesi Utara (Disperindag)," Jurnal Riset Ekonomi, Manajemen, Bisnis dan Akuntansi, vol. 
16, no. 1, pp. 587-597, 2016, doi: 10.35794/emba.v3i4.11083.

[6] I. Ajzen, The Theory of Planned Behavior, vol. 50, no. 2. 1991. doi: 10.1016/07495978(91)90020-T.

[7] A. Bandura, Self-efficacy: Toward a Unifying Theory of Behavioral Change, vol. 84, no. 2. 1977. doi: 10.1016/0146-6402(78)90002-4.

[8] J. Feist and G. J. Feist, Theories of Personality, 7th ed. McGraw-Hill Companies, Inc, 2009. doi: 10.5005/jp/books/11135_13.

[9] L. Masraroh, "Efektivitas Bimbingan Kelompok Teknik Modeling untuk Meningkatkan Self Efficacy Akademik Siswa," Universitas Pendidikan Indonesia, 2012.

[10] G. Sengke, "The Effect of Organizational Culture Towards Organizational Performance At Dinas Perindustrian Dan Perdagangan Provinsi Sulawesi Utara (Disperindag)," Jurnal Riset Ekonomi, Manajemen, Bisnis dan Akuntansi, vol. 16, no. 1, pp. 587-597, 2016, doi: 10.35794/emba.v3i4.11083.

[11] S. N. Rahmawati, "Membangun Budaya Wirausaha Melalui Peran Ibu Untuk Meningkatkan Nilai Tambah Ekonomi Keluarga (Studi Kasus Pada Siswa Smk Negeri 5, Jln Dr Cipto Nomor 121 Semarang)," Jurnal Riset Ekonomi Manajemen (REKOMEN), vol. 1, no. 1, pp. 79-88, 2017, doi: 10.31002/rn.v1i1.563.

[12] B. P. Y. Kurniawan and A. Galushasti, "Effectiveness of fine-moving value in developing theoretical model of organizational performance: A perspective of the theory of planned behavior," Academy of Strategic Management Journal, vol. 20, no. 3, pp. 1-13, Jun. 2021, Accessed: Sep. 09, 2021. [Online]. Available:

https://www.abacademies.org/articles/Effective ness-of-fine-moving-value-in-developingtheoretical-model-of-organizationalperformance-a-perspective-of-the-theory-ofplanned-behavior-1939-6104-20-3-749.pdf

[13] H. Sitompul, "Metode Keteladanan dan Pembiasaan dalam Penanaman Nilai-Nilai dan Pembentukan Sikap pada Anak," Jurnal Darul 'Ilmi, vol. 04, no. 01, pp. 54-62, 2016.

[14] S. Sukirman, "Jiwa Kewirausahaan dan Nilai Kewirausahaan Meningkatkan Kemandirian Usaha melalui Perilaku Kewirausahaan," Jurnal Ekonomi dan Bisnis, vol. 20, no. 1, p. 117, 2017, doi: 10.24914/jeb.v20i1.318.
[15] I. Ajzen, The Theory of Planned Behavior, vol. 50, no. 2. 1991. doi: 10.1016/07495978(91)90020-T.

[16] T. Hidayat, A. Galushasti, B. P. Y. Kurniawan, and R. S. Mahanani, "Fine Moving Value in Behavioral Anomalies to Minimize Poverty in Disadvantaged Areas," Review of Applied SocioEconomic Research, vol. 22, no. 2, pp. 78-85, Nov. 2021, doi: 10.54609/reaser.v22i2.112.

[17] N. Ramdhani, "Penyusunan Alat Pengukur Berbasis Theory of Planned Behavior," Buletin Psikologi, vol. 19, no. 2, pp. 55-69, 2011, doi: 10.22146/bpsi. 11557 .

[18] S. N. Rahmawati, "Membangun Budaya Wirausaha Melalui Peran Ibu Untuk Meningkatkan Nilai Tambah Ekonomi Keluarga (Studi Kasus Pada Siswa Smk Negeri 5, Jln Dr Cipto Nomor 121 Semarang)," Jurnal Riset Ekonomi Manajemen (REKOMEN), vol. 1, no. 1, pp. 79-88, 2017, doi: 10.31002/rn.v1i1.563.

[19] J. Jonnius, "Menumbuhkembangkan Budaya Kewirausahaan dalam Masyarakat," Menara, vol. 12, no. 1, pp. 48-55, 2013.

[20] N. Yulanda, "Pengaruh Nilai Budaya Bisnis pada Masyarakat Minangkabau terhadap Perilaku Kewirausahaan Pedagang Perantau di Tanah Abang," Journal of Applied Business and Economics, vol. 2, no. 1, pp. 97-108, 2015.

[21] S. Sukirman, "Jiwa Kewirausahaan dan Nilai Kewirausahaan Meningkatkan Kemandirian Usaha melalui Perilaku Kewirausahaan," Jurnal Ekonomi dan Bisnis, vol. 20, no. 1, p. 117, 2017, doi: $10.24914 /$ jeb.v20i1.318.

[22] J. Jonnius, "Menumbuhkembangkan Budaya Kewirausahaan dalam Masyarakat," Menara, vol. 12, no. 1, pp. 48-55, 2013.

[23] M. Poku and W. Ansah, "Entrepreneurial scaled behavioural indicators: Concept development and measure validation," Cogent Social Sciences, vol. 5, no. 1, 2019, doi: 10.1080/23311886.2019.1685366.

[24] I. M. Kirzner, Competition And Entrepreneurship. London: The University of Chicago, 1973.

[25] J. P. Kotter and J. L. Heskett, Corporate Culture and Performance. New York: Free Press, 1992.

[26] E. L. Paramita, C. Dwiatmadja, and I. W. Damayana, "Penyusunan Model Pengembangan Kewirausahaan Berbasis Kearifan Lokal Dalam Kewirausahaan Desa Adat di Bali," UNS SME's Summit \& Awards, vol. 4, pp. 354-360, 2015. 
[27] N. Ermawati, E. Soesilowati, and P. E. Prasetyo, "Pengaruh Need for Achivment Dan Locus of Control Terhadap Intensi Berwirausaha Melalui Sikap Siswa Kelas Xii Smk Negeri Se Kota Semarang," Journal of Economic Education, vol. 6, no. 1, pp. 66-74, 2017, doi: 10.15294/jeec.v6i1.14704.

[28] R. Q. Danish, J. Asghar, Z. Ahmad, and H. F. Ali, "Factors_affecting_entrepreneurial_cultur," Journal of Innovation and Entrepreneurship, vol. 10, no. 1, pp. 1-12, 2019.

[29] H. Welsa, "Pengaruh Kewirausahaan Terhadap Kemampuan Usaha Serta Kinerja Usaha," Ekuitas, vol. 13, no. 3, pp. 371-387, 2006.

[30] C. V. Djodjobo and H. N. Tawas, "Pengaruh Orientasi Kewirausahaan Inovasi Produk Dan Keunggulan Bersaing Terhadap Kinerja Pemasaran Usaha," Jurnal EMA, vol. 2, no. 3, pp. 1214-1224, 2014, doi: 10.47335/ema.v5i2.55.

[31] B. Tewal, Adolfina, M. Ch. H. Pandowo, and H. N. Tawas, Perilaku Organisasi. Patra Media Grafindo, 2017.

[32] N. H. Leff, "Entrepreneurship and Economic Development: The Problem Revisited," Journal of Economic Literature, vol. 17, no. 1, pp. 46-64, 1979.

[33] S. Beugelsdijk, "Entrepreneurial Culture, Regional Innovativeness and Economic Growth," ERSA Conference Papers, vol. 04, p. 210, 2004.

[34] Y. Rante, "Pengaruh Budaya Etnis dan Perilaku Kewirausahaan Terhadap Kinerja Usaha Mikro Kecil Agribisnis di Provinsi Papua," Jurnal Manajemen dan Wirausaha, vol. 12, no. 2, pp. 133-141, 2010, doi: 10.9744/jmk.12.2.pp.133141.

[35] C. Nachtigall, U. Kroehne, F. Funke, and R. Steyer, "(Why) Should we use SEM? Pros and cons of structural equation modeling," $M P R$ online, vol. 8, no. 2, pp. 1-22, 2003.

[36] B. G. Tabachnick and L. S. Fidell, Using Multivariate Statistics, 6th ed. Pearson, 2013. doi: 10.1037/022267.

[37] M. Igbaria, N. Zinatelli, P. Cragg, and A. L. M. Cavaye, "Personal Computing Acceptance Factors in Small Firms: A Structural Equation Model," MIS Quarterly: Management Information Systems, vol. 21, no. 3, pp. 279-305, 1997, doi: $10.2307 / 249498$.
[38] J. F. Hair, W. C. Black, B. J. Babin, and R. E. Anderson, Multivariate Data Analysis, New Intern. New Jersey: Pearson, 2014.

[39] R. M. Baron and D. A. Kenny, "The ModeratorMediator Variable Distinction in Social Psychological Research: Conceptual, Strategic, and Statistical Considerations," Journal of Personality and Social Psychologyl, vol. 51, no. 6, pp. 1173-1182, 1986, doi: 10.1037/00223514.51.6.1173. 